\title{
CEsifo WORKING

\section{Why Do Buyers Pay Different Prices for Comparable Products? Evidence from the Housing Market}

Ralph B. Siebert, Michael J. Seiler 


\section{Impressum:}

CESifo Working Papers

ISSN 2364-1428 (electronic version)

Publisher and distributor: Munich Society for the Promotion of Economic Research - CESifo

$\mathrm{GmbH}$

The international platform of Ludwigs-Maximilians University's Center for Economic Studies and the ifo Institute

Poschingerstr. 5, 81679 Munich, Germany

Telephone +49 (0)89 2180-2740, Telefax+49 (0)89 2180-17845, email office@cesifo.de

Editor: Clemens Fuest

https://www.cesifo.org/en/wp

An electronic version of the paper may be downloaded

- from the SSRN website: www.SSRN.com

- from the RePEc website: $\quad$ www.RePEc.org

- from the CESifo website: https://www.cesifo.org/en/wp 


\title{
Why Do Buyers Pay Different Prices for Comparable Products? Evidence from the Housing Market
}

\begin{abstract}
We focus on the housing market and examine why nonlocal home buyers (NLBs) pay 15 percent more for houses than local home buyers (LBs). We estimate a housing demand model that returns heterogeneous willingness to pay parameters for housing attributes. Our results show that NLBs are willing to pay more for specific housing attributes, especially for house size and school quality. We also find that gratification and reward arguments, and imperfect price information explain the price differential to a large extent. Search cost and house age arguments have an adverse effect on NLBs' house spending.
\end{abstract}

JEL-Codes: L130, L490, L630.

Keywords: heterogeneous preferences, housing market, imperfect information on price distributions, school quality, search costs.

\author{
Ralph B. Siebert \\ Purdue University \\ Krannert School of Management \\ Department of Economics \\ USA - West Lafayette, IN, 47906 \\ rsiebert@purdue.edu
}

\author{
Michael J. Seiler \\ The College of William and Mary \\ Department of Finance \\ PO Box 8795 \\ Williamsburg / VA / USA \\ mjseiler@wm.edu
}

May 23, 2020

We thank Jack Barron, Patrick Bayer, Kelly Bishop, Sara Fisher Ellison, Natalia Fabra, Sebastian Linde, Stephen Martin, Eugenio Miravete, and seminar participants for valuable feedback. We are grateful to the Tippecanoe County Assessor's Office, the Board of Realtors in Indiana, and the Real Estate Agents Association in Indiana for granting temporary access to their databases. All errors are our own. 


\section{Introduction}

Studies have shown that buyers frequently pay different prices for comparable products. Price variations are observed in a variety of markets, such as health care markets, automobile markets, and retail markets. ${ }^{1}$ In the real estate market, an established fact is that home buyers pay different prices for comparable houses (see, for example, Turnbull and Sirmans (1993), Lambson, McQueen, and Slade (2004), Ihlanfeldt and Mayock (2012), and He, Lin, Liu, and Seiler (2020)). This topic receives much attention by policy makers and scholars, especially since households spend large fractions of their income and wealth on purchasing homes.

Several real estate studies (see Clauretie and Thistle (2007) and Ihlanfeldt and Mayock (2012)) examine why home buyers who move into a market from out of town (nonlocal buyers, NLBs) pay more for houses than home buyers with local residential status (local buyers, LBs). Two relevant arguments have been identified to explain part of the observed price differential between NLBs and LBs: imperfect information on home price distributions and differential search costs. Our study builds on these arguments and considers a further aspect: heterogeneous preferences between NLBs and LBs that translate into differential demand for housing and neighborhood attributes and differential prices. The aspect of heterogeneous preferences has not yet received much attention in explaining the price differential.

Our study builds on a comprehensive dataset on house transactions that contains highly detailed information on individual buyers and house characteristics. We estimate a housing demand model that enables us to estimate buyer-specific willingness to pay parameters for housing and neighborhood attributes. The goal is to relate the individualspecific estimated willingness to pay parameters - for specific housing attributes - to derive differential demands for housing attributes and to explain the price differential between NLBs and LBs.

\footnotetext{
${ }^{1}$ For contributions in the health care markets, see Brown (2019), Cooper, Craig, Gaynor, and VanReenen (2019), and Grennan (2013); in the automobile markets, see Goldberg and Verboven (2001); and in the retail markets, see Hitsch, Hortacsu, and Lin (2019) and DellaVigna and Gentzkow (2019).
} 
Houses are characterized by a variety of attributes (such as house size, number of bedrooms, number of bathrooms, etc.) and associated neighborhood attributes (such as school quality, racial composition, etc.). Home buyers make their purchase decisions dependent on their preferences for these housing and community attributes. Our study highlights that buyer preferences for housing and neighborhood attributes can be rather different. These heterogeneous preferences determine buyer-specific willingness to pay and demand for housing and neighborhood attributes that translate into different prices paid for houses.

Home buyers' preferences can be different for several reasons: First, willingness to pay parameters are determined by demographic characteristics, such as income, and these can differ across home buyers as well as NLBs and LBs. For example, NLBs receiving highincome job offers may assign a higher willingness to pay to, say house size, and this would explain higher house spending. Second, buyers' willingness to pay is also determined by the buyers' residential status per se. For instance, NLBs move into a market from out of town and leave their familiar social environments. As a reward or gratification, they may be willing to spend more on housing attributes such as house size, school quality, etc. Hence, $N L B s^{\prime}$ residential status can exert an effect on willingness to pay and demand for housing attributes. Relatedly, NLBs face specific work-related deadlines to move, while LBs usually do not have this binding moving constraint. The moving deadline leaves NLBs less time and limits their search to find a low-priced house, which can affect their willingness to pay for houses (see also Cheng, Lin, Liu, and Seiler (2015)). The moving deadline also puts pressure on NLBs, which can result in a higher risk aversion strategy and diminish bargaining strength (see Ihlanfeldt and Mayock (2012) and Ehrlich (2013)).

The housing market is also characterized by imperfect information. One may argue that Internet applications provide fully transparent information about listed houses. In several instances, this publicized information can be useful only to a limited extent. For example, while the price is mentioned in house listings, it still remains unclear whether the posted house prices reflect the local market value since comparable houses can be 
valued very differently across geographic regions. ${ }^{2}$ It is argued that, prior to purchasing the home, LBs have more knowledge of local price distributions than NLBs who resided in other areas. NLBs must infer the true market value of a house, while forming expectations on the local price. Some studies show that these expectations are formed and anchored to prices that buyers were accustomed to at their previous residence, which can explain part of the price differential (see Clauretie and Thistle (2007) and Ihlanfeldt and Mayock (2012); a more detailed literature review is provided later).

Imperfect information also prevails in the housing market (regardless of Internet postings) because some housing and neighborhood features are not mentioned in public listings or they are difficult to convey truthfully. One example is the house condition that is not posted or may be difficult to judge since "false advertising" of attributes is difficult to prove (see Farrell (1980)). As a consequence, buyers will have to evaluate the condition of the house themselves by visiting houses on site. This information acquisition is associated with search and travel costs, which differ across buyers. NLBs have higher search costs than LBs since they incur higher travel expenses and more travel time to get on-site. ${ }^{3}$ Some studies have shown that buyers with higher search and travel costs have higher reservation prices and search less intensively, which can affect buyers' preferences for housing attributes. Our study takes into consideration that search and travel costs can affect buyers' willingness to pay and their demand for housing and neighborhood attributes.

We use a dataset that encompasses detailed home transaction information on buyers, houses, and neighborhoods in Indiana from 2000 to 2020. The database includes confidential buyer information such as mortgages and addresses prior to purchasing a new home. ${ }^{4}$ This information allows us to distinguish between buyers' local and nonlocal residential status when purchasing their home. We match buyer-level demographics to the willing-

\footnotetext{
${ }^{2}$ For example, a house in Beverly Hills, California, is valued and priced differently than a comparable house in Indiana.

${ }^{3}$ Turnbull and Sirmans (1993) and Elder, Zumpano, and Baryla (1999) have shown that NLBs face higher search and travel costs.

${ }^{4}$ We use this information from various sources, such as the Multiple Listing Services, the county assessor, and mortgage documents, which increases the reliability of distinguishing local from nonlocal buyers.
} 
ness to pay for housing and neighborhood attributes, which provides further insights into explaining the home price differentials between NLBs and LBs.

We estimate a housing demand model to uncover buyer-specific willingness to pay parameters of various housing and neighborhood attributes. These willingness to pay parameters are then explained by various buyer demographics, including residential buyer status. The estimates will give information on spending by NLBs and LBs on specific housing attributes.

Our estimation results show that NLBs spend $\$ 28,222$ (15 percent) more on houses than LBs. ${ }^{5}$ The decomposition of the price differential shows that the largest part of the price differential — $\$ 22,584$ or 12 percent of the house price - is explained by NLBs' higher willingness to pay for house size, and this is explained by the several arguments. First, NLBs assign an additional $\$ 4.53$ per square foot on willingness to pay, which is determined by their residential status per se and can be explained by reward and gratification arguments, as well as a deadline to move. These reasons explain that NLBs' spending on house size increases by $\$ 9,507$. Moreover, NLBs also experience higher demand on house size, which increases their house size expenditures by an additional $\$ 12,931$. Second, imperfect price information is a further argument that increases NLBs' expenses on houses size. Third, an additional $\$ 2,507$ (close to 1 percent of the house price) that is spent on house size is explained by higher income. It is noteworthy that income contributes little to explaining the price differential compared to residential status arguments (reward, gratification, and moving deadline) and imperfect price information. Finally, higher search and travel costs reduce NLBs' spending on house size. These arguments reduce NLBs' willingness to pay per square footage by $\$ 0.02$ for every additional mile that buyers have to travel.

Our results also show that NLBs spend an additional $\$ 11,059$ on better schools, but they spend $\$ 4,662$ less on house age. Wealth and bargaining strength arguments result in rather similar house spending between both groups of buyers.

To summarize, our results show that heterogeneous preferences between LBs and NLBs can explain largely different expenditures on house size, school quality, and house age.

\footnotetext{
${ }^{5}$ Local buyers pay an estimated average of $\$ 182,588$ for houses, while NLBs pay $\$ 210,810$.
} 
Accounting for all heterogeneous willingness to pay arguments adds up to a prediction that NLBs pay 15 percent more for houses.

The remainder of the paper is organized as follows: Section 2 provides an overview of the related literature. Section 3 describes the database sources and provides summary statistics. Section 4 describes our empirical model and the estimation procedure. We discuss the results in Section 5 and conclude in Section 6.

\section{$2 \quad$ Related Literature}

Our study is related to a large literature on imperfect price information (see Stigler (1961), Diamond (1971), and Rothschild (1974)). One might think that imperfect price information is not very pronounced in the housing market since Internet applications inform buyers about housing attributes such as prices. However, many nonlocal buyers are uncertain whether a posted price reflects the true local market value. This judgment requires knowledge of the local price distributions, and this differs between LBs and NLBs. Since nonlocal buyers usually have less knowledge of local price distributions prior to purchasing a home, they must form expectations on prices to infer the market value of a house (see Burdett and Judd (1983) and Favaray and Song (2014)). Several studies have shown that buyers with imperfect price information form expectations on prices that are based on anchors or reference prices (see Tversky and Kahneman (1974), Kahneman and Tversky (1979), Northcraft and Neale (1987), and Bucchianeri and Minson (2013)). Several empirical studies on the housing market adopted these anchor and reference price arguments (see Turnbull and Sirmans (1993) and Watkins (1998)). Lambson, McQueen, and Slade (2004) and Ihlanfeldt and Mayock (2012) test whether NLBs accustomed to high real estate prices in their home state pay a premium in low-price areas.

One might also think that imperfect information is less pronounced in the housing market due to the presence of real estate agents that serve as middlemen between buyers and sellers. However, the study by Levitt and Syverson (2008) shows that real estate agents act according to their own interests (earning a commission) and do not convey 
their knowledge of market conditions effectively. ${ }^{6}$

As mentioned earlier, home buyers will have to incur search or travel costs to inspect home conditions. Search costs determine reservation prices, which implies that buyers search less intensively, and this affects home prices (see, for example, Diamond (1971) and Rothschild (1974)). Studies find that differential search costs across buyers can lead to significant price dispersions and elevated prices. ${ }^{7}$ In the context of NLBs, Turnbull, and Sirmans (1993) and Elder, Zumpano, and Baryla (1999) show that NLBs face higher search and travel costs, often measured by distance to the location.

A further possible explanation of price differentials between NLBs and LBs is that NLBs often face specific deadlines to settle. A moving deadline constrains the search, leaves NLBs less time, and limits their home search. A deadline can affect NLBs' willingness to pay for housing attributes and their spending on housing. The moving deadline can also have implications on home buyers' bargaining strength. To avoid the risk of not being able to move prior to the deadline, NLBs might be more risk averse and submit higher bids than LBs, which increases the likelihood of getting an offer accepted. Ehrlich (2013) has shown that more eager buyers apply more risk-averse bidding strategies and submit higher bids. A related argument that could explain the price differential between NLBs and LBs is that the former leave their familiar social environments and, as gratification for moving, they reward themselves by spending more on housing and neighborhood attributes.

Several related studies focus on the question of whether nonlocal buyers pay premia in the real estate market. Myer, He, and Webb (1992) find no support for the hypothesis that nonlocal house buyers pay premia due to imperfect price information and search costs. Turnbull and Sirmans (1993) and Watkins (1998) also find that NLBs do not pay significantly more than LBs. In contrast, Lambson, McQueen, and Slade (2004) show that relative to LBs, NLBs pay a premium of about 5.5 percent for comparable houses.

\footnotetext{
${ }^{6}$ Due to data limitations, our study is not able to include the effect of agencies on house prices. This is certainly an interesting and important topic that will be discussed further at the end of the paper.

${ }^{7}$ See, for example, Salop and Stiglitz (1977), Varian (1980), Spulber (1995), and Janssen, MoragaGonzalez, and Wildenbeest (2005); see also Baye, Morgan, and Scholten (2006) for an overview.
} 
Ihlanfeldt and Mayock (2012) find that nonlocal buyers pay a premium of around 1.9 percent. Other studies show that imperfect price information can result in uninformed buyers purchasing low-quality goods for low prices (see Chan and Leland (1982), Chan and Leland (1986), and Dranove and Satterthwaite (1992)).

The following three studies are close to our paper: Ling, Naranjo, and Petrova (2018) consider the commercial real estate market using data on the 15 largest U.S. metropolitan areas from 1997 to 2011. Their data cover commercial property transactions, including industrial buildings, apartment complexes, and office properties. They find that nonlocal investors pay premia of 4 to 15 percent for commercial buildings. Their results show that search costs primarily explain the premia, while imperfect price information plays a less important role. Their study differs from ours in a variety of aspects: They focus on commercial real estate markets, while we consider residential markets. These markets are very different in their institutional and behavioral characteristics. First, in commercial real estate markets, business agents and investors make their purchasing decisions dependent on a variety of factors that include not only the price of the property, but additional business factors that relate to regional profitability, etc. The evaluation of business profitability differs among investors, and this becomes a critically important aspect in purchasing commercial real estate. These features, however, are not of primary importance in our study of the residential real estate market. Second, the commercial real estate market has different features and demand than the residential real estate market. For example, commercial properties sell for much higher prices - in Ling, Naranjo, and Petrova (2018)'s case between $\$ 2.1$ million and $\$ 7.2$ million - than the residential houses in our study (with an average transaction price of $\$ 189$ thousand). Finally, their study concentrates on local status and search cost arguments that are proxied by dummy variables. Our study puts the main focus on heterogeneous housing and neighborhood preferences between local and nonlocal buyers. We explain those preferences based on a set of buyer demographics that include residential status, search and travel costs, and imperfect price information. 
The study by Chinloy, Hardin, and Wu (2013) also focuses on the commercial real estate market. Their study highlights that the investors' experience explains the price differentials. They argue that buyers' local experience and repeated transactions help build human capital, which reduces search costs. Their results confirm that experienced buyers receive acquisition discounts, while inexperienced local buyers receive no or little discount. Again, our focus - the residential real estate market - is substantially different than the commercial real estate market. Moreover, Chinloy, Hardin, and Wu (2013) highlight the relevance of experience when comparing different buyers. Our study relates price differentials to heterogeneous buyer preferences that are explained by buyer demographics.

The study by Holmes and Xie (2018) focuses on the residential real estate market in Johnson County, Indiana, from 2004 to 2010. Their study shows that nonlocals sell at a 21 percent discount compared to local sellers. Their research differs from ours in that they focus mostly on out-of-state sellers, which is explained by the fact that their geographic housing market encompasses a large fraction (12 percent) of nonlocal sellers. Since their study explains why out-of-state sellers sell for lower prices, they control for arguments such as foreclosure and rental and vacant properties. In contrast, our market is characterized by a larger fraction of nonlocal buyers, while the fraction of out-of-state sellers is rather small. Therefore, we concentrate on explaining buyer-specific preferences by search and travel costs, reference prices, etc.

Home buyers' willingness to pay for housing and neighborhood attributes can be determined by a variety of buyer demographics. Several empirical housing studies focus on estimating the willingness to pay across buyers for specific attributes (see Cutler and Glaeser (1997), Epple (1987), Epple and Sieg (1999), Levitt and Syverson (2008), and Nechyba and Strauss (1998)). Studies found that wealthier families have a higher willingness to pay for larger houses in neighborhoods that are safer and have better schools (see also Bayer, Ferreira, and McMillan (2007), Betts (1995), Black (1999), Card and Krueger (1996), and Hanushek (1996)). A number of empirical studies show that racial demo- 
graphics affect sale prices (see, for example, Harding, Rosenthal, and Sirmans (2003), Yinger (1978), and Ihlanfeldt and Mayock (2009)). Studies also show that income, public good preferences, and heterogeneous housing stocks have an effect on buyer preferences (see Epple and Sieg (1999) and Sieg, Smith, Banzhaf, and Walsh (2002)).

We estimate a demand model, similar to Bishop and Timmins (2019), that returns individual-specific preferences for housing and neighborhood characteristics. We allow residential status per se (NLB versus LB) to have an effect on buyers' willingness to pay and demand through gratification, reward, and moving deadline arguments. Heterogeneous preferences will help us explain the price differentials between local and nonlocal buyers.

In sum, our study differs from earlier studies, as we explain the price differential between local and nonlocal buyers in the residential real estate market while paying special attention to heterogeneous preferences across buyers for housing and neighborhood attributes.

\section{Data Sources and Descriptives}

We established a database on the residential housing market for West Lafayette and Lafayette, Indiana, that includes house transactions from 2000 to $2020 .^{8}$ The housing market is an appropriate setting for our research since it is characterized by several arguments, including imperfect information on prices, heterogeneous preferences, and differential search and travel costs across buyers. The housing market is also an important market since a home is typically a person's most valuable asset.

The Lafayette area is characterized by stable housing prices over time and is generally unaffected by speculation and bubbles. ${ }^{9}$ Stable housing prices are an advantage for our purposes, as we explain price differentials by imperfect information and heterogeneous

\footnotetext{
${ }^{8}$ From now on, we simply refer to Lafayette.

${ }^{9}$ For information on the evolution of housing prices and appreciation rates in different states, see the U.S. Census Bureau at http://www.census.gov/const/www/quarterly starts completions.pdf and OFHEO at http://www.ofheo.gov/media/hpi/2q07hpi.pdf. All monetary values in this study are expressed in 2020 U.S. dollars using the Consumer Price Index.
} 
preferences. The Lafayette area is populated by residents who are employed by or study at Purdue University and work mainly at research facilities, manufacturing firms, and service providers.

Our database relies on several sources. Information on housing attributes were provided by the Tippecanoe Multiple Listing Services, the Tippecanoe County Assessor's Office and Home Junction. The Multiple Listing Services (MLS) database is a comprehensive database used by real estate agents. It contains detailed information on houses listed in the real estate market, such as the address of the house, the final sale or transaction price, the house size, the number of bedrooms, the number of bathrooms, days on the market, and lot size. ${ }^{10}$

The Tippecanoe County Assessor's Office and Home Junction provided us with home buyer information, partly based on the Home Mortgage Disclosure Act. ${ }^{11}$ We received the buyers' residence information; that is, their addresses prior to buying a house in Lafayette. Their residential information (prior to moving) allows us to categorize them into NLBs and LBs. This distinction between NLBs and LBs is appropriate since it captures the fact that some (originally nonlocal) residents may rent a house or apartment before purchasing a home. In this case, these purchasers will appropriately be registered as LBs since they had opportunities to collect local information on neighborhoods during their rental period. We also retrieved buyers' mortgage information, which allows us to control for wealth effects since wealthier home buyers presumably hold smaller mortgage loans. It has also been shown that higher mortgage rates increase sellers' reservation prices (see Genesove and Mayer (1997, 2001)). Neighborhood demographics are collected from the census at the disaggregate (tract) level. Finally, we match the data using ArcGIS coding to derive geographic measures. As a result, our database contains detailed information on different housing characteristics, neighborhood demographics, and other buyer sociodemographic attributes that include residential information prior to purchasing the new

\footnotetext{
${ }^{10}$ In comparing our database with the Census of Population and Housing database, the latter database contains self-reported or estimated home values, which are less reliable than the house prices in our database. Moreover, the prices are partitioned into 23 mutually exclusive categories, and this represents a loss of information compared to our pricing data.

${ }^{11}$ The identities and some other information about the home buyers are kept anonymous in the study.
} 
home, mortgages, travel distance, and reference prices (more details follow later).

Table 1, upper panel, shows information on the demographics in Lafayette. The area is populated with 180,952 people, of which 79 percent are White, 5 percent are Black, 8 percent are Hispanic, and 8 percent are Asian. The median household income amounts to $\$ 44,161$ per year, which is below the national median household income of $\$ 63,030$. Lafayette schools are evaluated on average at 3.18 points on a five-point scale. The average unemployment rate amounts to 2.6 percent.

We consider only residential houses and remove commercial sales and apartments from the database. ${ }^{12}$ After removing the bottom and top 1 percent of observations of the Saleprice, Housesize, and Baths distributions and removing houses that have been listed for more than 365 days, we are left with 19, 539 house transaction from 2000 to 2020 for our analysis. NLBs from 40 different U.S. states purchased 510 of the houses. ${ }^{13}$ Table 1, lower panel, shows that most nonlocal buyers come from California (16 percent), Connecticut (13 percent), Illinois (12 percent), Texas (12 percent), Pennsylvania (5 percent), and Ohio (4 percent).

We consider the following housing, neighborhood, and household characteristics: ${ }^{14}$

\section{Variable Description}

(1) Saleprice: Final sale price of the house;

(2) Housesize: Size of the house in square footage;

(3) Bedrooms: Number of bedrooms;

(4) Baths: Number of full bathrooms;

(5) Houseage: Age of the house;

(6) DOM: Days on the market;

(7) Distance: Buyer's distance from his/her former residence to the new home. This measure is used to proxy for search and travel costs (see also Turnbull and Sirmans (1993) and Elder, Zumpano, and Baryla (1999));

(8) Referenceprice: Median house price in the buyer's former home state. This measure is used to proxy for NLBs' imperfect information on price distributions (see also Clauretie and Thistle (2007) and Ihlanfeldt and Mayock (2012));

\footnotetext{
${ }^{12}$ Most apartments in Lafayette are rental properties, so we would not expect any crucial concerns from removing these.

${ }^{13}$ We dropped house purchases by non-U.S. residents.

${ }^{14}$ This includes most of the variables that have been provided to us.
} 
(9) NLB: The nonlocal buyer dummy takes a value of one (zero) if the house was purchased by a buyer with nonlocal (local) residential status prior to purchasing the house. This dummy variable will pick up remaining nonlocal buyer effects that determine the willingness to pay for house size, school quality, and house age (as will be explained later). The willingness to pay for house attributes can be higher for nonlocal buyers due to gratification and reward reasons since they leave their familiar social environments. Moreover, nonlocal buyers frequently face strict deadlines to move, which would shorten their search and increase reservation and purchase price. We expect the nonlocal residential status to have a positive effect on their willingness to pay for housing attributes.

(10) Mortgagerate: It is measured by the mortgage amount divided by the sale price. It is used as a control variable for liquidity and wealth effects, since wealthier home buyers take out smaller mortgage loans;

(11) Schoolscore: School scores of public elementary schools (on a scale from 1 to 5, with 5 being the highest quality rating);

(12) Income: Income information;

(13) Unemployment: Unemployment in percentage in the (census tract) neighborhood where a house is located;

(14) White: Percentage of White residents in the (census tract) neighborhood where a house is located;

(15) Black: Percentage of Black residents in the (census tract) neighborhood where a house is located;

(16) Hispanic: Percentage of Hispanic residents in the (census tract) neighborhood where a house is located;

(17) Asian: Percentage of Asian residents in the (census tract) neighborhood where a house is located;

(18) Season: The Lafayette market is characterized by seasonal effects, where most houses are sold from March to September. Therefore, we consider a seasonal dummy that takes on a value of one if a house is sold during this period.

(19) YearFE: Year fixed effects, from 2000 to 2020;

(20) TractFE: Dummy variables that refer to census tracts.

In the following, we provide summary statistics of housing and neighborhood characteristics, as well as buyer-specific information. Tables 2 and 3 show the summary statistics for houses purchased by LBs and NLBs, respectively. LBs spend on average $\$ 188,906$ for housing, while nonlocal residents spend $\$ 205,601$. In the following, we provide further details on housing and buyer characteristics that could explain this large sale price difference. One explanatory factor could be that LBs and NLBs have different bargaining 
strengths. As mentioned earlier, NLBs often face deadlines for moving. To avoid the risk of not being able to move prior to the deadline, an NLB might submit a higher bid than an LB to enhance the chances of getting an offer accepted. In this case, the relative difference between the final list price and the sale price - bargain $=(($ LastListprice Saleprice)/Listprice)*100 - would be larger for NLBs than for LBs. ${ }^{15}$ A mean comparison of the variable shows that the means of the bargaining variables are 3.42 percent for LBs and 3.14 percent for NLBs. The difference in the bargaining spread is rather small and explains only a price difference of 0.3 percentage points or $\$ 567$. To provide further insight, we applied a simple multivariate regression analysis in which we regressed the bargaining variable on an NLB dummy as well as buyer and neighborhood attributes such as Distance, Referenceprice, Mortgagerate, Income, Schoolscore, Black, Hispanic, Asian, and year fixed effects. ${ }^{16}$ The estimation results return an insignificant coefficient estimate on the NLB dummy variable, providing evidence that differential bargaining strengths do not have a significant effect on explaining the house price differential.

Turning to a comparison of housing characteristics between both groups, the houses purchased by NLBs are 10 percent larger $(2,101$ square feet) than those purchased by LBs (1,911 square feet). Interestingly, accounting for differential house sizes, NLBs and LBs seem to pay about the same average price per foot — $\$ 98$ and $\$ 99$, respectively. It should be noted that this comparison is based on an overall average price per square foot across group members. Later, we will address the point that the willingness to pay per square foot is different across house buyers depending on their demographics, including the buyers' residential status. Houses have about the same number of bedrooms and bathrooms and similar lot size across both groups. Houses across both groups are different in their ages. LBs buy houses that are significantly older (by 42 percent or 11 years) than the houses purchased by NLBs. This difference will be addressed later.

The neighborhood characteristics for houses purchased by LBs and NLBs are not significantly different with one exception: NLBs choose houses in better school districts.

\footnotetext{
${ }^{15}$ For further information on list price strategies in the housing market, see Beracha and Seiler (2014) and Cardella and Seiler (2016).

${ }^{16}$ The estimation results are available from the author upon request.
} 
Their school quality measure is 16 percent higher. Hence, education is a more important feature for NLBs than for LBs, which needs to be accounted for when explaining the price difference.

Next, we focus on buyer characteristics. One important aspect to consider is that Indiana has one of the lowest average real estate prices in the U.S. This implies that NLBs possibly sold their previous homes for more than the average house price in Indiana. This wealth effect would allow NLBs to cover part of their home expenditures and to finance their houses on a smaller mortgage. Our data show that the groups have a similar Mortgagerate (measured by mortgage amount divided by sale price), around 0.82 . This comparison hints toward the fact that wealth does not explain why NLBs spent more on houses. A further argument that supports this notion is that the U.S. government subsidizes mortgage debt in a variety of ways, especially up to an $80 \%$ loan-to-value ratio. Therefore, it often is a lucrative option for home buyers to take out large mortgages independent of their wealth status.

As mentioned earlier, home buyers usually go on site to inspect houses. Visiting houses involves a search cost that differs across buyers. Potential buyers have to travel, and they incur travel expenses that vary depending on the distance they travel from their home residence before purchasing a house. Nonlocal buyers have to spend more money and time compared to local buyers. As shown in Table 3, the average travel distance for NLBs is 1,005 miles, and the maximum is 2,217 miles.

Turning to the imperfect price information argument, local buyers had the advantage of gaining information on local market values and prices throughout their residency. In contrast, nonlocal buyers faced the challenge that houses are valued differently across geographic regions. Hence, nonlocal residents likely face higher uncertainty in evaluating whether posted prices of homes in Lafayette properly reflect their market values. In order to infer the true market value of a house, NLBs have to form expectations on prices. As mentioned in the introduction, expectations are formed based on anchors or reference prices. We follow previous studies and assume that home buyers' price expectations are 
anchored to prices they were accustomed to at their previous residence (see Lambson, McQueen, and Slade (2004) and Ihlanfeldt and Mayock (2012)). We assume that the average house price in their state serves as a proxy for forming their price expectations. Tables 2 and 3 show that the average home price in states outside Indiana (Stateprice) is $\$ 325,892$, which is significantly higher than the average price in the housing market in Lafayette $(\$ 188,906)$. This gives rise to the fact that NLBs may overestimate local housing prices. We, therefore, consider home prices in states outside Indiana (Referenceprice) as a relevant variable to proxy imperfect information on local price distributions to explain the price difference.

To summarize, our descriptives show that NLBs pay more for houses than LBs. We find that NLBs buy larger and newer houses in better school districts. We, therefore, devote special attention in our demand estimation to these specific housing attributes (Housesize, Schoolscore, and Houseage) and treat them as endogenous regressors.

In the next section, we introduce our demand model, which enables us to disentangle the price differential while explicitly accounting for buyers' different willingness to pay for housing characteristics.

\section{The Model and Estimation}

Our study applies a demand estimation that allows for individual-specific preferences for housing and neighborhood characteristics. The heterogeneous preferences will help us explain the price differentials between local and nonlocal buyers. Our housing model follows Bishop and Timmins (2019). Their estimator is appropriate for our purposes, since it enables us to flexibly estimate individual preferences for different characteristics, while allowing for potentially endogenous regressors, that is, Housesize, Schoolscore, and Houseage.

The model relates the price $(P)$ of a house to its characteristics. We distinguish between exogenous housing and neighborhood attributes that enter $H$, potential endogenous housing characteristics that are included in $Z$, and unobserved housing and neighborhood 
attributes that are captured by $\epsilon$. The subindex $i=1, \ldots, N$ refers to households. ${ }^{17}$

The house price is described by a function that maps the characteristics into the price:

$$
P=P\left(Z_{i}, H_{i}, \epsilon_{i} ; \beta\right),
$$

where $\beta$ is the parameter of interest, which reflects the implicit prices for housing and neighborhood characteristics.

Consumer utility is a function of $Z, H, \epsilon$, and the consumption of a composite commodity is denoted by $c$. Consumer preferences also depend on observed household attributes, $X$, and on unobserved household attributes, $\nu$. The utility is defined as:

$$
U=U\left(Z_{i}, H_{i}, \epsilon_{i}, C_{i}, X_{i}, \nu_{i} ; \alpha_{j}\right)
$$

where $\alpha$ is a parameter vector. Normalizing the price of the composite commodity to 1 , we consider the following budget constraint:

$$
I_{i} \geq P\left(Z_{i}, H_{i}, \epsilon_{i} ; \beta\right)+C_{i}
$$

Under that assumption that the budget constraint is binding, we can write utility as:

$$
U=U\left(Z_{i}, H_{i}, \epsilon_{i},\left(I_{i}-P\left(Z_{i}, H_{i}, \epsilon_{i} ; \beta\right)\right), X_{i}, \nu_{i} ; \alpha_{j}\right)
$$

We follow the standard assumption in the literature that the utility function is quasilinear and additively separable in $Z, H$, and $\epsilon$ :

$$
U=\alpha_{0}+\alpha_{1} Z_{i}+\frac{1}{2} \alpha_{2} Z_{i}^{2}+\alpha_{3} X_{i} Z_{i}+\nu_{i} Z_{i}+g\left(H_{i}, \epsilon_{i}\right)+\left(I_{i}-P\left(Z_{i}, H_{i}, \epsilon_{i} ; \beta\right) .\right.
$$

\footnotetext{
${ }^{17}$ For notational simplicity, we suppress time subscripts.
} 
Taking the first-order condition with respect to $Z$ and solving for $P^{\prime}$ gives us:

$$
P^{\prime}\left(Z_{i} ; \beta\right)=\alpha_{1}+\alpha_{2} Z_{i}+\alpha_{3} X_{i}+\nu_{i}
$$

where $\nu$ is treated as a regression error and $P^{\prime}(Z ; \beta)$ is replaced with the implicit price we receive from estimating the pricing function.

Since $Z$ presumably varies with observable household characteristics $X$, unobservable preference shocks, $\nu$, and the parameters of the hedonic price function, $\beta$, the estimation of equation (6) results in a potential biased estimate for $\alpha_{2}$. We therefore apply a change of variables (from $Z$ to $\nu$ ) approach and solve equation (6) for $\nu_{i}$ :

$$
\nu_{i}=P^{\prime}\left(Z_{i} ; \beta\right)-\alpha_{1}+\alpha_{2} Z_{i}+\alpha_{3} X_{i}
$$

Recovering the implicit price in the first stage, assuming that $\nu$ is normally distributed, $\mathrm{N}\left(0, \sigma^{2}\right)$, we can estimate equation ( 7$)$ by maximum likelihood. The likelihood is written as:

$$
\Pi_{i=1}^{N} l\left(\alpha, \sigma ; Z_{i}, X_{i}\right)=\Pi_{i=1}^{N} \frac{1}{\sigma \sqrt{2 \pi}} \exp \left\{-\frac{1}{2 \sigma^{2}}\left(\nu(\alpha)^{2}\right)\right\}\left|\frac{\partial \nu_{i}(\alpha)}{\partial Z_{i}}\right|
$$

where

$$
\left|\frac{\partial \nu_{i}(\alpha)}{\partial Z_{i}}\right|=P^{\prime \prime}\left(Z_{i} ; \hat{\beta}\right)-\alpha_{2}
$$

We now turn to introducing the estimation procedure that closely follows Bishop and Timmins (2019). It consists of two steps. In the first step, we estimate the house price function to get the implicit prices, the $\beta$ parameters. More specifically, we estimate the following price function:

$$
P\left(Z_{i}, H_{i}, \epsilon_{i} ; \beta\right)=H_{i}^{\prime} \beta^{H}+f\left(Z_{i} ; \beta\right)+\epsilon_{i}
$$


where $H$ includes linear and quadratic functions in each of the following housing and neighborhood attributes: Bedrooms, Baths, Lotsize, DOM, Income, Unemployed, Black, Hispanic, and Asian. The $Z$ is comprised of the potential endogenous regressors (Housesize, Schoolscore, and Houseage) that enter in linear and quadratic form. To control for potentially correlated unobservables at the neighborhood level, we use a set of neighborhood fixed effects at the census tract level. We also include several fixed effects such as seasonal and year fixed effects.

In order to estimate the function $f\left(Z_{i} ; \beta\right)$, we must first control for the variation in price due to other housing characteristics. We first estimate $\beta^{H}$ and then move $H^{\prime} \hat{\beta}^{H}$ to the left-hand side and specify the function $f$ as being locally quadratic in $Z$, which results in:

$$
P\left(Z_{i}, H_{i}, \epsilon_{i} ; \beta\right)-H_{i}^{\prime} \beta^{H}=\beta_{0, i^{*}}+\beta_{1, i^{*}} Z_{i}+\beta_{2, i^{*}} Z_{i}^{2}+\epsilon_{i}
$$

where $i^{*}$ highlights the fact that the $\beta$ coefficients can be interpreted as the implicit prices faced by household $i$ in the market. The hedonic gradient $\left(\beta_{1, i^{*}} Z_{i}+\beta_{2, i^{*}} Z_{i}^{2}\right)$ can be estimated from equation (11). ${ }^{18}$

The second step concentrates on the estimation of the $\alpha$ parameters that is based on equation (7) in combination with the maximum likelihood. It focuses on the following equation that describes consumers' willingness to pay function for housing attributes given their consumer demographics $(X)$ :

$$
P^{\prime}\left(Z_{i} ; \beta\right)=\alpha_{1}+\alpha_{2} Z_{i}+X_{i}^{\prime} \alpha_{3}+\nu_{i}
$$

where $X_{i}$ is comprised of buyer demographics including residential status, Distance, Referenceprice, Mortgagerate, and race variables (Black, Hispanic, and Asian where White is the excluded variable).

\footnotetext{
${ }^{18}$ We followed Bishop and Timmins (2019) and applied several robustness tests that included a weighted least squares regression based on different bandwidths that range from 2 to 3 times the standard deviations of the housing characteristics.
} 


\section{The Results}

This section presents the estimation results of our empirical model. We begin with discussing the first-stage estimation results of the price equation, which provides insights into the implicit prices for various housing and neighborhood characteristics. Second, we estimate the heterogeneous willingness to pay parameters across buyers for specific house characteristics. We attribute these heterogeneous preferences to buyer characteristics (such as Distance, Referenceprice, Mortgagerate, NLB status per se, etc.) and determine their contribution to explaining the price differential between NLBs and LBs.

\subsection{Estimation Results of the Pricing Function}

For estimating the pricing equations (10 and 11), we use 19,539 observations in the estimations. The results are shown in Table 4. All parameter estimates (except the estimate on squared income) are highly significant. Using the estimated coefficients on the house and neighborhood characteristics, we predict house prices of $\$ 182,588$ and $\$ 210,810$ for LBs and NLBs, respectively. Hence, prices are predicted at a 98 percent accuracy, which confirms the good fit of our regression. The predicted price differential between LB and NLB is $\$ 28,222$ or 15 percent of the average house price.

Column (1) of Table 4 shows the parameter estimates, and Column (2) displays the calculated average marginal effects. The magnitudes of our housing and neighborhood estimates are in line with findings from previous studies on the housing market, which further confirms the reliability of our estimation results. Focusing on the implicit prices for housing attributes, the estimation results return an average willingness to pay of $\$ 72$ for one additional square foot. Since NLBs purchase larger houses than LBs, this will explain part of the price differential (as will be detailed later). The estimation results also show that buyers are willing to pay $\$ 3,507$ for a 20 percent improvement in school quality. The parameter estimate on bedrooms shows that home buyers are willing to spend an additional $\$ 2,768$ per bedroom. One additional bathroom adds $\$ 11,349$ to the total sale price. An increase in lot size by one acre raises the house price by $\$ 24,911$. The 
coefficient estimate on house age indicates that home buyers spend $\$ 691$ less if house age increases by one year. ${ }^{19}$ The parameter estimate on days on the market shows that the sale price decreases by $\$ 46$ for an additional day that the house is listed on the market.

Our estimation results return negative implicit prices for neighborhoods with higher unemployment rates and for Hispanic communities. The sale prices increase with income, and we find positive marginal effects for Black and Asian neighborhoods. Finally, we find that house prices increase by $\$ 1,737$ if they are sold in high season.

In the next step, we are interested in explaining the price differential between LBs and NLBs based on the estimated average implicit prices. Using the parameter estimates, as shown in Table 4, we compare the NLBs' and LBs' average expenses on specific house and neighborhood characteristics. These calculated expenses will provide an idea as to what extent the price differential could be explained by differing demands on housing characteristics, evaluated at the average implicit prices.

Columns 1 and 2 of Table 5 predict how much LBs and NLBs (respectively) spend on average on specific house and neighborhood characteristics. Column 3 shows the corresponding extra expenses carried out by NLBs, and column 4 displays these extra expenses in percentages relative to the house sale price. First, evaluating the average implicit price for house size at the sample means of LB and NLBs, Table 5 (column 3) shows that NLBs spend an extra $\$ 13,605$ (7 percent of the house price) on purchasing larger houses than LBs. Moreover, NLBs pay an additional $\$ 1,781$ or (one percent of the sale price) for better school quality. House age is a further characteristic that stresses differential spending between both buyer groups. NLBs pay an extra $\$ 7,383$ (or 4 percent of the sale price) due to purchasing newer homes. ${ }^{20}$

The last line in Table 5 shows that LBs spend in total $\$ 182,588$ on these characteristics, while NLBs spend in total $\$ 210,810$. The price differential amounts to $\$ 28,222$ or 15 percent of the house price. The three characteristics alone (Housesize, Schoolscore, and

\footnotetext{
${ }^{19}$ It should be noted that the estimated parameter reflects preferences (or implicit prices) averaged across all buyers. We turn to the estimation of individual-specific willingness to pay parameters in the second stage of our estimation procedure.

${ }^{20}$ Remember that this prediction is evaluated at the average implicit price.
} 
Houseage $)$ already cover a large amount $-\$ 22,770(=\$ 13,605+\$ 1,781+\$ 7,383)$ - of the total $\$ 28,222$ price differential. The three characteristics also coincide with the summary statistics that show different averages across both home buyer groups.

In summary, our price equation estimates return predicted prices with 98 percent accuracy. The estimates return a total price differential of $\$ 28,222$ or 15 percent of the house sale price. A large part, $\$ 22,770$, of the price differential can be explained by NLBs' extra expenditures (evaluated at the average willingness to pay) on house size, school quality, and house age. Next, we devote special attention to the fact that buyer groups may be characterized by heterogeneous willingness to pay parameters for housing characteristics.

\subsection{Estimation Results of Individual's Willingness to Pay Pa- rameters}

We evaluate buyers' heterogeneous preferences for housing characteristics. We focus on the estimation of buyer-specific willingness to pay parameters. More specifically, we estimate heterogeneous willingness to pay parameters for three housing attributes: house size, school quality, and house age. (We focus on those characteristics since our summary

statistics have returned largely different means across both buyer groups.) The demand for these housing attributes was largely different across LBs and NLBs based on the summary statistics and the first-stage estimation results.

We are especially interested in disentangling the extent to which heterogeneous willingness to pay for the three housing characteristics (explained by buyer-specific demographics) can predict the price differential. We put special attention on the following buyer-specific demographics: (a) non-residential buyer status per se (measured by an NLB dummy), (b) search costs (measured by Distance), and (c) imperfect price information (measured by Referenceprice). We also account for further buyer demographics that are included in the $X$ (see equation (12)).

Table 6, column (1), shows the estimation results for the heterogeneous willingness to 
pay parameters on house size. The negative parameter estimate on Housesize reflects the downward-sloping individual demand for house size. The inverse demand has an intercept of around $\$ 79$, and the negatively estimated slope indicates that the willingness to pay for an additional square foot decreases by $\$ 0.003$. Evaluating the inverse demand at the buyers' quantity decisions for house size predicts that LBs spend $\$ 73.8$ per square foot, while NLBs spend $\$ 73.3$ per square foot. Evaluating these prices at the sample means, for NLBs and LBs, shows that LBs spend $\$ 141,052$ on house size, while NLBs spend $\$ 153,983$. Hence, NLBs spend an extra $\$ 12,931$ for additional demand on house size. Furthermore, focusing on the residential argument, as measured by the $N L B$ dummy, the parameter estimate shows that NLBs assign a higher willingness to pay of $\$ 4.53$ per square foot. This explains an additional expense for house size of $\$ 9,507$ that NLBs spend beyond the $\$ 12,931$ that is paid extra for additional demand on house size. This premium of $\$ 9,507$ could be explained by NLB status arguments, such as reward, gratification, and the deadline for moving.

Turning to the travel and search cost argument, as measured by Distance, our results (see Table 6, column (1)) show that the willingness to pay for house size decreases by $\$ 0.02$ for every mile that buyers live farther away from Lafayette. The estimate provides evidence that travel and search costs reduce willingness to pay for house size. Evaluating this estimate in terms of price per square foot shows that LBs' willingness to pay for a square foot decreases from $\$ 73.8$ to $\$ 73.6$, while the corresponding per square foot price for NLBs drops from $\$ 73.3$ to $\$ 49.6$. Evaluating the estimate at the sample means for distance and house size shows that NLBs pay $\$ 49,413$ less on house size due to higher search and travel costs.

Regarding the imperfect information on price argument, we find that the coefficient on Referenceprice is positive. This predicts an extra expense of $\$ 19$ per square foot paid by NLBs. Evaluating the estimate at the corresponding means predicts that NLBs spend an additional $\$ 44,286$ on house size due to imperfect information on prices.

The positive estimate on Mortgagerate shows that home buyers with higher mort- 
gages spend more on house size. Moreover, income is positively correlated with house size preferences. In comparing the premium paid due to income differences $(\$ 1,625)$ and residential status as measured by the NLB dummy $(\$ 9,507)$, it is noteworthy that residential status arguments (reward, gratification, moving deadline) explain a price difference that is about five times higher than the price differential explained by income. Finally, the last line in Table 6 shows NLBs' additional willingness to pay for house size accounting for heterogeneous preferences. Overall, NLBs are paying $\$ 22,584$ more on house size than LBs, which appears to be a reasonable number to explain the total price differential between both buyer groups.

Table 7 shows the willingness to pay for school quality explained by buyer demographics. Notable is the result that home buyers are willing to pay an additional $\$ 8,904$ for a 20 percent increase in school quality. This result confirms that school quality is a highly regarded attribute among home buyers. The estimation results also show that the non-residential status per se (measured by the NLB dummy) predicts that NLBs pay an additional $\$ 3,226$ for better schools, which could partly be explained by reward and gratification arguments. The last line in the table shows that, overall, NLBs pay an additional $\$ 11,059$ for school quality.

Finally, Table 8 shows the extra expenses for house age. Most noteworthy is the result that the willingness to pay for house age increases with house age itself, as shown by the parameter estimate for house age. This could be related to the fact that older houses are characterized by a specific architectural design that is hard to find or that older houses are located in preferred locations (for example, near parks, downtown, etc.). Since NLBs buy newer houses, they spend $\$ 13,204$ less. The parameter estimate on the NLB dummy variable shows that NLBs are willing to spend $\$ 2,086$ less due to their residential status. The lower preference for house age could be explained by NLBs not wanting to invest effort in fixing older houses but preferring to move into well-maintained homes, which would allow them to concentrate more on their new job, etc. There could also be underlying factors that correlate with house age, such as preferred locations that are known by LBs 
but not by NLBs. The last line in Table 8 shows that NLBs spend $\$ 4,662$ less on houses due to their age. ${ }^{21}$

\section{Conclusion}

Buyers pay different prices for comparable products in many markets, including health care, food, and housing. The purpose of this study is to explain why nonlocal home buyers (persons who moved from out of town) pay higher prices for houses than local home buyers. Our study shows that NLBs pay $\$ 28,222$ (15 percent) more for houses. Based on a dataset that encompasses highly detailed and confidential information on individual buyers and house characteristics, we explore the merits of several arguments that explain the price differential. While accounting for arguments that have been addressed in earlier studies, we pay special attention to heterogeneous preferences between buyers.

We estimate a housing demand model that allows for the flexible estimation of buyerspecific willingness to pay parameters for housing and neighborhood attributes. The estimation results show that the largest part of the price differential $(\$ 22,585$ or 12 percent of the house price) is explained by their higher willingness to pay and extra expenses for house size. A further large expenditure $(\$ 11,059$ or 6 percent) is explained by NLBs' higher willingness to pay for school quality. Finally, we find that NLBs save $\$ 4,662$ (that is a 3 percent reduction of the house price) due to lower expenses on house age.

It is interesting to note that a large part of the price differential is explained by status arguments (reward, gratification, and moving deadline) and imperfect price information. A higher search cost results in buyers spending less on their homes, especially on their willingness to pay for house size. We show that heterogeneous preferences between LBs and NLBs can explain a large part of the price differential. Wealth and bargaining strengths are similar between both groups of buyers.

For future research, it would be interesting to focus on additional sources of imperfect

\footnotetext{
${ }^{21}$ Note that this results from estimating heterogeneous willingness to pay parameters, which can result in different results when compared to the first-stage estimates that are averaged across all buyers.
} 
information such as imperfect information on quality (i.e., attributes that are unobserved to the uninformed buyers, but observed by the informed buyers). For example, local home buyers may have an informational advantage over nonlocal home buyers due to better knowledge of neighborhoods, crime rates, infrastructure, etc. In this regard, it would be insightful to examine whether nonlocal and less-informed buyers purchase houses with significantly inferior quality.

It would also be interesting to focus on the role of real estate agents in explaining house prices and paid price differentials. There is an extensive literature that focuses on the effects of real estate agents on buyers and prices (see Bernheim and Meer (2008), Genesove and Mayer (1997), and Merlo and Ortalo-Magne (2004)). This research is motivated by real estate markets being characterized by imperfect information on the seller and buyer sides. Real estate agents provide information and reduce search costs. They also provide professional services and negotiating skills. Agents are typically involved in many tasks such as advertising, accompanying potential buyers on home visits, conducting open houses, negotiating offers, etc. While they have an information advantage, their effort and quality are difficult to observe, which can result in shirking behavior.

Based on these arguments, studies investigate whether real estate agents can mitigate information asymmetries and eliminate behavioral biases (see also Campbel and Kracaw (1980), Anand and Subrahmanyam (2008), and Ling, Naranjo, and Petrova (2018)). Levitt and Syverson (2008) and Rutherford, Springer, and Yavas (2005, 2007) find that price discounts are larger when sellers are less informed. Similarly, Holmes and Xie (2018) find that homes of out-of-state sellers are sold at a discount.

Price distortions can also be caused by dual agency relationships, defined as the seller and buyer agents being employed by the same real estate firm. In this regard, Kadiyali, Prince, and Simon (2014) and Johnson, Lin, and Xie (2015) investigate the effect of dual agency on sale price. The study by Gardiner, Heisler, Kallberg, and Liu (2007) suggests that dual agency reduces sale prices and decreases the time a house is listed on the market.

While the effects of real estate agencies on transaction prices is an important topic 
that can contribute to explaining the price differential between local and nonlocal buyers, we are not able to focus on this aspect due to data limitations. At this point, we defer to the fact that all our house transactions were listed on the MLS, and a necessary condition to get access to the MLS is that sellers are represented by a broker. Therefore, all house transactions involved a seller's agent, which adds some degree of homogeneity in our study and attenuates major concerns that nonlocal and local home buyers would receive differential agency support. However, the role of real estate agents on explaining the house price differentials is certainly a relevant aspect to consider in future work. We certainly agree that further work on different markets is warranted to test whether the main mechanisms and arguments (such as heterogeneous willingness to pay, imperfect information on prices and qualities, and differential search costs) also apply to different regions and markets.

On a final note, our study contributes to debates that center on imperfect information and market imperfections, and these topics are of long-standing interest to distinguished scholars and policy makers. In order to diminish this market imperfection problem, information transparency policies are considered that mandate professionals (such as pharmacies, hospitals, physicians, dentists, lawyers, and online providers) to provide more product information. The topic of imperfect information attracted further interest and practical relevance with the introduction of Internet applications. One recent example is the health market, where hospitals in the U.S. are required to publish their charge master prices online from 2019 onward. Proponents of price transparency policies often argue that further price information may be beneficial to consumers, as it can reduce prices. Opponents fight on the grounds that price and quality provisions are not independent, such that more price information can increase quality uncertainty and harm consumers via quality deterioration. Our study suggests that transparency policies targeting markets with imperfect information on price could be beneficial for consumers. 


\section{References}

Anand, A. and A. Subrahmanyam, 2008, "Information and the Intermediary: Are Market Intermediaries Informed Traders in Electronic Markets?," Journal of Financial and Quantitative Analysis, Vol. 43, pp. 1-28.

Baye, M., J. Morgan and P. Scholten, 2006, "Information, Search, and Price Dispersion," in Handbook of Economics and Information Systems, Amsterdam.

Bayer, P., F. Ferreira, and R. McMillan, 2007, "A Unified Framework for Measuring Preferences for Schools and Neighborhoods," Journal of Political Economy, Vol. 115, pp. 588-638.

Campbel, T.S. and W. Kracaw, 19807, "Information Production, Market Signaling, and the Theory of Financial Intermediation," Journal of Finance, Vol. 35, pp. 863-882.

Beracha, E. and M.J. Seiler, 2014, "The Effect of Listing Price Strategy on Transaction Selling Prices," Journal of Real Estate Finance and Economics, Vol. 49, pp. 237255.

Bernheim, B.D., and J. Meer , 2008, "How Much Value Do Real Estate Brokers Add? A Case Study," NBER working paper no. 13796.

Betts, J.R., 1995, "Does School Quality Matter? Evidence from the National Longitudinal Survey of Youth," Review of Economics and Statistics, LXXVII, pp. 231-250.

Black, S.E., 1999, "Do Better Schools Matter? Parental Valuation of Elementary Education," Quarterly Journal of Economics, Vol. 114, pp. 577-599.

Brown, Z., 2019, "Equilibrium Effects of Health Care Price Information, Review of Economics and Statistics, Vol. 101, pp. 699-712.

Bucchianeri, G.W. and J.A. Minson, 2013, “A Homeowner's Dilemma: Anchoring in Residential Real Estate Transactions, Journal of Economic Behavior and Organization, Vol. 89, pp. 76-92. 
Card, D. and A.B. Krueger, 1996, "Labor Market Effects of School Quality: Theory and Evidence," NBER Working Paper No. 5450.

Cardella, E., and M.J. Seiler, 2016, "The Effect of Listing Price Strategy on Real Estate Negotiations: An Experimental Study," Journal of Economic Psychology, Vol. 52, pp. 71-90.

Case, K. and R. Shiller, 2003, "Is There a Bubble in the Housing Market?," Brookings Papers on Economic Activity, pp. 299-342.

Clauretie, T.M., and P.D. Thistle, 2007, "The Effect of Time-On-Market and Location on Search Costs and Anchoring: The Case of Single-Family Properties," The Journal of Real Estate Finance and Economics, Vol. 35, pp. 181-196.

Chan, Y.S. and H.E. Leland, 1982, "Prices and Qualities in Markets with Costly Information," The Review of Economic Studies, Vol. 49, pp. 499-516.

Chan, Y.S. and H.E. Leland, 1986, "Prices and Qualities: A Search Model," Southern Economic Journal, Vol. 52, pp. 1115-1130.

Cheng, P., Z. Lin, Y. Liu, and M.J. Seiler, 2015, "The Benefit of Search in Housing Markets," Journal of Real Estate Research, Vol. 37, pp. 597-621.

Chinloy, P., W. Hardin III, and Z. Wu, 2013, "Price, Place, People, and Local Experience," Journal of Real Estate Research, Vol. 35, pp. 477-505.

Cooper, Z., S.V. Craig, M. Gaynor, and J. VanReenen, 2019, “The Price Ain’t Right? Hospital Prices and health Spending on the Privately Insured, The Quarterly Journal of Economics, pp. 51-107.

Cutler, D. and E. Glaeser, 1997, "Are ghettos good or bad?," Quarterly Journal of Economics, Vol. 112, pp. 827-872.

DellaVigna, S. and M. Gentzkow, 2019, "Uniform Pricing in U.S. Retail Chains, NBER working paper, 23996. 
De los Santos, D., A. Hortacsu and M. Wildenbeest, 2012, "Testing Models of Consumer Search Using Data on Web Browsing and Purchasing Behavior," American Economic Review, 102, pp. 2955-2980.

Diamond, P.A., 1971, "A Model of Price Adjustment," Journal of Economic Theory, Vol. 3, pp. 156-168.

Dranove, D. and M.A. Satterthwaite, 1992, "Monopolistic Competition when Price and Quality are Imperfectly Observable," The RAND Journal of Economics, Vol. 23, pp. 518-534.

Ehrlich, G., 2013, "Price and Time to Sale Dynamics in the Housing Market: The Role of Incomplete Information" mimeo.

Elder H.W., L.V. Zumpano and E.A. Baryla, 1999, "Buyer Search Intensity and the Role of the Residential Real Estate Broker," Journal of Real Estate Finance and Economics, Vol. 18, pp. 351-368.

Epple, D., 1987, "Hedonic Prices and Implicit Markets: Estimating Demand and Supply Functions for Differentiated Products," J.P.E., 95 (February), pp. 59-80.

Epple, D. and H. Sieg, 1999, "Estimating Equilibrium Models of Local Jurisdictions," Journal of Political Economy, 107 (August), pp. 645-681.

Fan, J. and I. Gijbels, 1996, "Local Polynomial Modeling and its Applications," Chapman and Hall, London.

Farrell, J., 1980, "A Model of Price and Quality Choice, With Informed and Uninformed Buyers," mimeo, Department of Economics, M.I.T.

Gardiner, J., J. Heisler, J. Kallberg and C. Liu, 2007, "The Impact of Dual Agency," Journal of Real Estate Finance and Economics, Vol. 35, pp. 39-55.

Genesove, D. and C.J. Mayer, 1997, "Equity and Time to Sale in the Real Estate Market," American Economic Review, Vol. 87, pp. 255-269. 
Goldberg, P. and F. Verboven, 2001, "The Evolution of Price Dispersion in the European Car Market, Review of Economic Studies, Vol. 68, pp. 811-848.

Grennan, M., 2013, "Price Discrimination and Bargaining: Empirical Evidence from Medical Devices, The American Economic Review, Vol. 103, pp. 145-177.

Haerdle, W. M. Mueller, S. Sperlich, A. Werwatz, 2004, "Nonparametric and Semiparametric Models," Springer.

Hanushek, E.A., 1996, "Measuring Investment in Education," Journal of Economic Perspectives, X, " pp. 9-30.

Harding, J.P., S.S. Rosenthal, and C.F. Sirmans, 2003, "Estimating Bargaining Power in the Market for Existing Homes," Review of Economics and Statistics, Vol. 85, pp. $178-188$.

He, X., Z. Lin, Y. Liu, and M.J. Seiler, 2020, "Search Benefit in Housing Markets: An Inverted U-Shaped Price and TOM Relation," Real Estate Economics, forthcoming.

Hitsch, G., A. Hortacsu, X. Lin, 2019, "Prices and Promotions in U.S. Retail Markets: Evidence from Big Data, NBER working paper, 26306.

Holmes, C. and J. Xie, 2018, "Distortions in Real Estate Transactions with Out-of-State Participants" The Journal of Real Estate Finance and Economics, Vol. 57, pp. $592-617$.

Hortacsu, A. and C. Syverson 2004, "Product Differentiation, Search Costs and Competition in the Mutual Fund Industry," Quarterly Journal of Economics, Vol. 119, pp. 403-456.

Ihlanfeldt, K. and T. Mayock, 2012, "Information, Search, and House Prices: Revisited," Journal of Real Estate Financial Economics, Vol. 44, pp. 90-115.

Johnson, K., Z. Lin and J. Xie, 2015, "Dual Agent Distortions in Real Estate Transactions," Real Estate Economics, Vol. 43, pp. 507-536. 
Lambson, V.E., R.G. McQueen, and B.A. Slade, 2004, "Do Out of State Buyers Pay More for Real Estate? An Examination of Anchoring Induced Bias and Search Costs," Real Estate Economics, Vol. 32, pp. 85-126.

Levitt, S.D. and C. Syverson, 2008, "Market Distortions When Agents Are Better Informed: The Value of Information in Real Estate," Review of Economics and Statistics, 90, pp. 599-611.

Ling, D.C., A. Naranjo, and M.T. Petrova, 2018, "Search Costs, Behavioral Biases, and Information Intermediary Effects," The Journal of Real Estate Finance and Economics, 57, pp. 114-151.

Merlo, A. and F. Ortalo-Magne, 2004, "Bargaining over Residential Real Estate: Evidence from England, " Journal of Urban Economics 56, pp. 192-216.

Myer, N.F.C., L.T. He, and J. R. Webb, 1992, "Sell-offs of U.S. Real Estate: The Effect of Domestic Versus Foreign Buyers on Shareholder Wealth," Journal of the American Real Estate and Urban Economics Association, Vol. 20, pp. 487-500.

Nechyba, T.J., and R.P. Strauss, 1998, "Community Choice and Local Public Services: A Discrete Choice Approach," Regional Sci. and Urban Economics, 28 (January), pp. 51-73.

Rothschild, M., 1974, "Searching for the Lowest Price When the Distribution of Prices Is Unknown," Journal of Political Economy, Vol. 82, pp. 689-711.

Rutherford, R., T. Springer, and A. Yavas, 2005, "Conflicts between Principals and Agents: Evidence from Residential Brokerage," Journal of Financial Economics, Vol. 76, pp. 627-665.

Rutherford, R., T. Springer, and A. Yavas, 2007, "Evidence of Information Asymmetries in the Market for Residential Condominiums," Journal of Real Estate Finance and Economics, Vol. 35, pp. 23-38. 
Salop, S. and J. Stiglitz, 1977, "Bargains and Ripoffs: A Model of Monopolistically Competitive Price Dispersion," Review of Economic Studies, Vol. 44, pp. 493-510.

Salz, T., 2015, "Intermediation and Competition in Search Markets: An Empirical Case Study," mimeo.

Silverman, B.W., 1986, "Density Estimation for Statistics and Data Analysis," Vol. 26 of Monographs on Statistics and Applied Probability, Chapman and Hall, London.

Stigler, G.J., 1961, "The Economics of Information," Journal of Political Economy, Vol. 69, pp. 213-225.

Turnbull, G., and C.F. Sirmans, 1993, "Information, Search, and House Prices," Regional Science and Urban Economics, Vol. 23, pp. 545-557.

Varian, H., 1980, “A Model of Sales," American Economic Review, Vol. 70, pp. 651-659.

Watkins, C., 1998, “Are New Entrants to the Residential Property Market Informationally Disadvantaged?," Journal of Property Research, Vol. 15, pp. 57-70. 


\section{A Appendix: Tables}

Table 1: Lafayette Demographics, Census Data

\begin{tabular}{lc}
\hline \hline Demographics & Lafayette \\
\hline Population & 180,952 \\
White (in percent) & 78.61 \\
Black (in percent) & 5.01 \\
Hispanic (in percent) & 8.39 \\
Asian (in percent) & 7.99 \\
Income & $44,160.57$ \\
Schoolscore & 3.18 \\
Houseage & 43.29 \\
Unemployed & 2.59 \\
\hline \hline
\end{tabular}

\begin{tabular}{lc}
\hline \hline Top Nonlocal Buyers 2000-2020 \\
\hline California & $16 \%$ \\
Connecticut & $13 \%$ \\
Illinois & $12 \%$ \\
Texas & $12 \%$ \\
Pennsylvania & $5 \%$ \\
Ohio & $4 \%$ \\
\hline \hline
\end{tabular}

Table 1, upper panel, shows the demographics for Lafayette and West Lafayette, Indiana in 2019 (except household income is from 2015). The lower panel shows the origins of top nonlocal buyers. Sources: https://www.ffiec.gov/census/default.aspx and Multiple Listing Services. 
Table 2: Housing and Neighborhood Attributes: Local Buyers

\begin{tabular}{lrrr}
\hline \hline Housing and Neighborhood Attributes: Local Buyers, 19,029 obs & & & \\
Variable & Mean & Min & Max \\
\hline Saleprice & 188,906 & 50,061 & 940,308 \\
Housesize & 1,911 & 750 & 7,175 \\
Bedrooms & 3.31 & 1 & 7 \\
Baths & 1.91 & 1 & 6 \\
Houseage & 36.03 & 0 & 120 \\
DOM & 63 & 0 & 365 \\
Bargain & 3.42 & -19.44 & 87.03 \\
Distance & 7 & 0 & 196 \\
Referenceprice & 187,872 & 155,640 & 238,994 \\
Mortgagerate & 0.83 & 0 & 0.98 \\
Unemployed & 2.59 & 1.1 & 13 \\
Income & 65,470 & 9,514 & 122,360 \\
Schoolscore & 3.17 & 1 & 5 \\
White & 82.44 & 61.01 & 98.43 \\
Black & 3.71 & 0 & 22.54 \\
Hispanic & 8.68 & 0.97 & 28.30 \\
Asian & 5.17 & 0 & 33.19 \\
\hline \hline
\end{tabular}

Table 2 presents summary statistics for characteristics of houses purchased by local buyers. Source: Multiple Listing Services and Census.

Table 3: Housing and Neighborhood Attributes: Nonlocal Buyers

\begin{tabular}{lrrr}
\hline \hline Housing and Neighborhood Attributes: Nonlocal Buyers, 510 obs & & & \\
Variable & Mean & Min & Max \\
\hline Saleprice & 205,601 & 85,002 & 940,308 \\
Housesize & 2,101 & 825 & 6,588 \\
Bedrooms & 3.44 & 2 & 6 \\
Baths & 2.08 & 1 & 5 \\
Houseage & 25.35 & 0 & 119 \\
DOM & 49.50 & 0 & 310 \\
Bargain & 3.14 & -14.29 & 45.96 \\
Distance & 1,005 & 167 & 2,217 \\
Referenceprice & 325,892 & 131,268 & 788,964 \\
Mortgagerate & 0.82 & 0.22 & 0.98 \\
Unemployed & 2.65 & 1.1 & 6 \\
Income & 68,247 & 26,725 & 117,130 \\
Schoolscore & 3.68 & 2 & 5 \\
White & 82.55 & 61.01 & 98.43 \\
Black & 3.18 & 0 & 16.22 \\
Hispanic & 8.51 & 0.97 & 28.30 \\
Asian & 5.76 & 0 & 33.19 \\
\hline \hline
\end{tabular}

Table 3 presents summary statistics for characteristics of houses purchased by nonlocal buyers. Source: Multiple Listing Services and Census. 
Table 4: Results for Pricing Equation

\begin{tabular}{|c|c|c|}
\hline $\begin{array}{l}\text { Endogenous Variable: } \\
\text { Regressors }\end{array}$ & $\begin{array}{l}\text { Saleprice } \\
\text { (1) }\end{array}$ & $\begin{array}{c}\text { Marginal Effects } \\
(2)\end{array}$ \\
\hline Intercept & $\begin{array}{c}122,075^{* * *} \\
(17,371)\end{array}$ & \\
\hline Housesize & $\begin{array}{c}78.94^{* * *} \\
(2.81)\end{array}$ & 71.70 \\
\hline Housesize $^{2}$ & $\begin{array}{c}-0.189 \mathrm{E}-2^{* * *} \\
(0.49 \mathrm{E}-3)\end{array}$ & \\
\hline Schoolscore & $\begin{array}{r}-15,040^{* * *} \\
(4,036.65)\end{array}$ & $3,506.86$ \\
\hline Schoolscore ${ }^{2}$ & $\begin{array}{l}2,914.82^{* * *} \\
(708.53)\end{array}$ & \\
\hline Houseage & $\begin{array}{c}-1,434.84^{* * *} \\
(64.52)\end{array}$ & -691.20 \\
\hline Houseage $^{2}$ & $\begin{array}{c}10.39^{* * *} \\
(0.67)\end{array}$ & \\
\hline Bedrooms & $\begin{array}{c}12,226 \\
(5,131.35)\end{array}$ & $2,768.08$ \\
\hline Bedrooms ${ }^{2}$ & $\begin{array}{c}-1,427.85 \\
(711.73)\end{array}$ & \\
\hline Baths & $\begin{array}{r}-30,964^{* * *} \\
(3,633.19)\end{array}$ & $11,349.17$ \\
\hline Baths $^{2}$ & $\begin{array}{c}11,076^{* * *} \\
(785.84)\end{array}$ & \\
\hline Lotsize & $\begin{array}{l}27,231 * * * \\
(1,399.76)\end{array}$ & $24,910.94$ \\
\hline Lotsize $^{2}$ & $\begin{array}{c}-2,142.59^{* * *} \\
(175.57)\end{array}$ & \\
\hline$D O M$ & $\begin{array}{c}-72.67^{* * *} \\
(19.16)\end{array}$ & -46.30 \\
\hline$D O M^{2}$ & $\begin{array}{c}0.21^{* * *} \\
(0.07)\end{array}$ & \\
\hline Income & $\begin{array}{c}0.33^{* *} \\
(0.15)\end{array}$ & 0.27 \\
\hline Income ${ }^{2}$ & $\begin{array}{l}-4.37 \mathrm{E}-7 \\
(1.04 \mathrm{E}-6)\end{array}$ & \\
\hline Unemployed & $\begin{array}{c}-11,992 \\
(2,082.99)\end{array}$ & $-1,226.20$ \\
\hline Unemployed $^{2}$ & $\begin{array}{l}2,073.57 \\
(309.23)\end{array}$ & \\
\hline Black & $\begin{array}{c}1,037.02^{* *} \\
(538.10)\end{array}$ & 40.06 \\
\hline Black $^{2}$ & $\begin{array}{c}-135.22 * * * \\
(26.65)\end{array}$ & \\
\hline Hispanic & $\begin{array}{c}-3,040.52^{* * *} \\
(361.65)\end{array}$ & $-1,226.20$ \\
\hline Hispanic $^{2}$ & $\begin{array}{c}99.93^{* * *} \\
(12.35)\end{array}$ & \\
\hline Asian & $\begin{array}{l}3,566.23^{* * *} \\
(273.72)\end{array}$ & $2,616.38$ \\
\hline Asian $^{2}$ & $\begin{array}{c}-91.31^{* * *} \\
(8.59)\end{array}$ & \\
\hline Season & $\begin{array}{c}1,736.81^{* * *} \\
(1,056.19)\end{array}$ & \\
\hline YearFE & yes & \\
\hline TractFE & yes & \\
\hline $\begin{array}{l}\text { Obs: 19,539 } \\
\text { Adj. R-squared }\end{array}$ & 0.79 & \\
\hline
\end{tabular}

Table 4 shows the estimation results of the pricing equations (10 and 11). The dependent variable is the sale price. The third column shows the marginal effects. The estimation procedure is described in the text. Standard errors are shown in parentheses below the parameter estimates, and ${ }^{* *},{ }^{* *}$ and ${ }^{*}$ denote $99 \%, 95 \%$, and $90 \%$ levels of significance, respectively. 
Table 5: Comparison of Home Expenses by Characteristics

\begin{tabular}{lcccc}
\hline \hline & $\begin{array}{c}\text { Expenses } \\
\text { by LBs }\end{array}$ & $\begin{array}{c}\text { Expenses } \\
\text { by NLBs }\end{array}$ & $\begin{array}{c}\text { Extra Expenses } \\
\text { by NLBs }\end{array}$ & $\begin{array}{c}\text { Extra Expenses } \\
\text { by NLBs }\end{array}$ \\
Characteristics & $(1)$ & $(2)$ & $(3)$ & $(4)$ \\
\hline Housesize & 137,041 & 150,647 & 13,605 & 7.45 \\
Schoolscore & 11,112 & 12,894 & 1,781 & 0.98 \\
Houseage & $-24,906$ & $-17,523$ & 7,383 & 4.04 \\
Bedrooms & 9,158 & 9,515 & 356 & 0.20 \\
Baths & 21,625 & 23,655 & 2,030 & 1.11 \\
Lotsize & 13,495 & 13,203 & -292 & -0.16 \\
DOM & $-4,578$ & $-3,597$ & 981 & 0.54 \\
Income & 17,540 & 18,284 & 744 & 0.41 \\
Unemployed & $-3,180$ & $-3,244$ & -64 & -0.04 \\
Black & 149 & 128 & -21 & -0.01 \\
Hispanic & $-11,349$ & $-11,134$ & 215 & 0.12 \\
Asian & 13,538 & 15,058 & 1,520 & 0.83 \\
Season & 2,942 & 2,925 & -17 & -0.01 \\
\hline Saleprice & 182,588 & 210,810 & 28,222 & 15.46 \\
\hline \hline
\end{tabular}

Table 5 shows the average home expenses by (observed) home characteristics for NLBs and LBs. The expenses are calculated based on the estimation results of the pricing equations (10 and 11). 
Table 6: Willingness to Pay for House Size

\begin{tabular}{|c|c|c|c|c|}
\hline $\begin{array}{l}\text { Endog. Var.: } \\
\text { Regressors }\end{array}$ & $\begin{array}{c}\text { Parameter Estimates } \\
\text { (1) }\end{array}$ & $\begin{array}{c}\text { Local Buyers } \\
(2)\end{array}$ & $\begin{array}{c}\text { Nonlocal Buyers } \\
(3)\end{array}$ & $\begin{array}{c}\text { Difference } \\
(4)\end{array}$ \\
\hline Housesize & $\begin{array}{l}-0.003^{* * *} \\
(0.057 \mathrm{E}-3)\end{array}$ & 141,052 & 153,983 & 12,931 \\
\hline Schoolscore & $\begin{array}{c}1.386^{* * *} \\
(0.042)\end{array}$ & 8,396 & 10,708 & 2,313 \\
\hline Houseage & $\begin{array}{l}0.036^{* * *} \\
(0.001)\end{array}$ & 2,506 & 1,938 & -568 \\
\hline$N L B$ & $\begin{array}{l}4.525^{* * *} \\
(0.389)\end{array}$ & 0 & 9,507 & 9,507 \\
\hline Distance & $\begin{array}{c}-0.024^{* * *} \\
(0.001)\end{array}$ & -315 & $-49,728$ & $-49,413$ \\
\hline Referenceprice & $\begin{array}{c}0.136 \mathrm{E}-3^{* * *} \\
(2.172 \mathrm{E}-6)\end{array}$ & 48,835 & 93,122 & 44,286 \\
\hline Mortgagerate & $\begin{array}{c}11.375^{* * *} \\
(0.296)\end{array}$ & 18,051 & 19,641 & 1,590 \\
\hline Income & $\begin{array}{c}0.089 \mathrm{E}-3^{* * *} \\
(2.827 \mathrm{E}-6)\end{array}$ & 11,137 & 12,762 & 1,625 \\
\hline Black & $\begin{array}{c}0.254^{* * *} \\
(0.016)\end{array}$ & 1,801 & 1,699 & -102 \\
\hline Hispanic & $\begin{array}{c}0.183^{* * *} \\
(0.009)\end{array}$ & 3,027 & 3,264 & 237 \\
\hline Asian & $\begin{array}{l}0.081^{* * *} \\
(0.008) \\
\end{array}$ & 799 & 978 & 178 \\
\hline $\begin{array}{l}\text { Sum } \\
\text { Obs: } 19,539\end{array}$ & & 235,604 & 257,874 & 22,584 \\
\hline
\end{tabular}

Table 6 shows the estimation results for the individual preferences as shown in equation (12). The dependent variable is the individuals' willingness to pay parameters for house size. ${ }^{* * *}$ denotes a $99 \%$ level of significance. 
Table 7: Willingness to Pay for School Quality

\begin{tabular}{|c|c|c|c|c|}
\hline $\begin{array}{l}\text { Endog. Var.: } \\
\text { Regressors }\end{array}$ & $\begin{array}{c}\text { Parameter Estimates } \\
\text { (1) }\end{array}$ & $\begin{array}{c}\text { Local Buyers } \\
(2)\end{array}$ & $\begin{array}{c}\text { Nonlocal Buyers } \\
(3)\end{array}$ & $\begin{array}{c}\text { Difference } \\
(4)\end{array}$ \\
\hline Housesize & $\begin{array}{c}-0.212^{* * *} \\
(0.011)\end{array}$ & $-1,034$ & $-1,348$ & -314 \\
\hline Schoolscore & $\begin{array}{c}2,560.96^{* * *} \\
(8.255)\end{array}$ & 25,715 & 34,618 & 8,903 \\
\hline Houseage & $\begin{array}{c}-7.055^{* * *} \\
(0.250)\end{array}$ & -806 & -658 & 148 \\
\hline$N L B$ & $\begin{array}{c}877.53^{* * *} \\
(75.577)\end{array}$ & 0 & 3,226 & 3,226 \\
\hline Distance & $\begin{array}{l}4.566^{* * *} \\
(0.099)\end{array}$ & 16,872 & 16,771 & \\
\hline Referenceprice & $\begin{array}{l}-0.026^{* * *} \\
(0.042 \mathrm{E}-2)\end{array}$ & $-15,663$ & $-31,524$ & $-15,861$ \\
\hline Mortgagerate & $\begin{array}{c}-2,205.83^{* * *} \\
(57.367)\end{array}$ & $-5,804$ & $-6,665$ & -862 \\
\hline Income & $\begin{array}{l}-0.017^{* * *} \\
(0.055 \mathrm{E}-2)\end{array}$ & $-3,564$ & $-4,311$ & -747 \\
\hline Black & $\begin{array}{c}-49.245^{* * *} \\
(3.089)\end{array}$ & -579 & -577 & 2.55 \\
\hline Hispanic & $\begin{array}{c}-35.396^{* * *} \\
(1.889)\end{array}$ & -973 & $-1,108$ & -135 \\
\hline Asian & $\begin{array}{c}-15.685^{* * *} \\
(1.553) \\
\end{array}$ & -257 & -332 & -75 \\
\hline $\begin{array}{l}\text { Sum } \\
\text { Obs: } 19,539\end{array}$ & & $-2,863.92$ & 8,195 & 11,059 \\
\hline
\end{tabular}

Table 7 shows the estimation results for the individual preferences as shown in equation (12)). The dependent variable is the individuals' willingness to pay parameters for school quality. ${ }^{* * *}$ denotes a $99 \%$ level of significance. 
Table 8: Willingness to Pay for House Age

\begin{tabular}{|c|c|c|c|c|}
\hline $\begin{array}{l}\text { Endog. Var.: } \\
\text { Regressors }\end{array}$ & $\begin{array}{c}\text { Parameter Estimates } \\
\text { (1) }\end{array}$ & $\begin{array}{c}\text { Local Buyers } \\
(2)\end{array}$ & $\begin{array}{c}\text { Nonlocal Buyers } \\
(3)\end{array}$ & $\begin{array}{c}\text { Difference } \\
(4)\end{array}$ \\
\hline Housesize & $\begin{array}{c}-0.019^{* * *} \\
(0.001)\end{array}$ & 1,475 & 942 & -533 \\
\hline Schoolscore & $\begin{array}{c}-25.207^{* * *} \\
(0.761)\end{array}$ & $-2,878$ & $-2,349$ & 529 \\
\hline Houseage & $\begin{array}{c}20.137^{* * *} \\
(0.023)\end{array}$ & 26,145 & 12,942 & $-13,204$ \\
\hline$N L B$ & $\begin{array}{c}-82.277^{* * *} \\
(7.089)\end{array}$ & 0 & $-2,086$ & $-2,086$ \\
\hline Distance & $\begin{array}{l}0.428^{* * *} \\
(0.009)\end{array}$ & 108 & 10,909 & 10,801 \\
\hline Referenceprice & $\begin{array}{c}-0.247 \mathrm{E}-2^{* * *} \\
(0.039 \mathrm{E}-3)\end{array}$ & $-16,721$ & $-20,406$ & $-3,685$ \\
\hline Mortgagerate & $\begin{array}{c}-206.835^{* * *} \\
(5.385)\end{array}$ & $-6,188$ & $-4,309$ & 1,879 \\
\hline Income & $\begin{array}{c}-0.161 \mathrm{E}-2^{* * *} \\
(0.051 \mathrm{E}-3)\end{array}$ & $-3,798$ & $-2,785$ & 1,013 \\
\hline Black & $\begin{array}{c}-4.617^{* * *} \\
(0.289)\end{array}$ & -617 & -373 & 245 \\
\hline Hispanic & $\begin{array}{c}-3.319^{* * *} \\
(0.177)\end{array}$ & $-1,038$ & -716 & 321 \\
\hline Asian & $\begin{array}{c}-1.470^{* * *} \\
(0.146) \\
\end{array}$ & -274 & -214 & 59 \\
\hline $\begin{array}{l}\text { Sum } \\
\text { Obs: } 19,539\end{array}$ & & $-3,787$ & $-8,448$ & $-4,662$ \\
\hline
\end{tabular}

Table 8 shows the estimation results for the individual preferences as shown in equation (12). The dependent variable is the individuals' willingness to pay parameters for house age. ${ }^{* * *}$ denotes a $99 \%$ level of significance. 